Biochemistry Unit., New-Valley Lab.

Animal Health Research Institute.

\title{
TRACE ELEMENTS VARIATION IN BLOOD SERUM OF SHEEP SUFFERING FROM INTERNAL PARASITES IN RECENTLY RECLAIMED AREAS (DARB AL-ARBAIYN) IN THE WESTERN EGYPTIAN DESERT
}

(With 2 Tables and 3 Figures)

By

\section{M.A. SALEH; A. ABOU EL-ELA and F.A. OSMAN*}

Parasitology Unit, New-Valley Lab., Animal Health Research Institute

(Received at 17/12/2006)

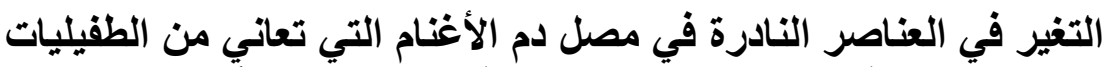

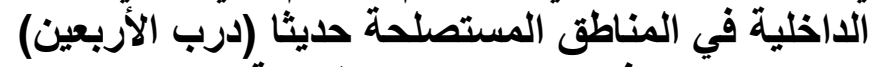

في صحراء مصر الغربية

مصطقى أحمد صالح ، علي أبو العلا ، فتحي أحمد عثمان

تعاني الأغنام التي ترعى على الأراضي المستصلحة حديثا بالو ادي الجديد من اضطر العاب في

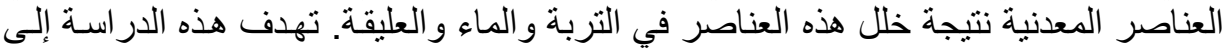

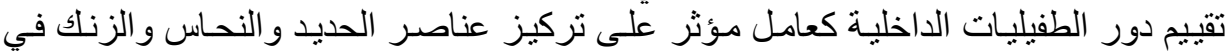

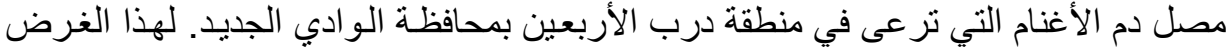

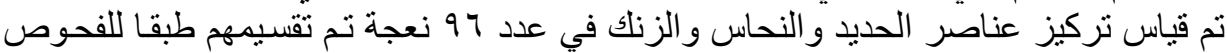

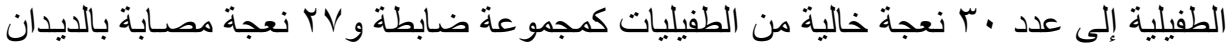

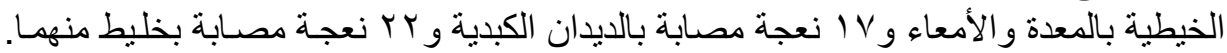

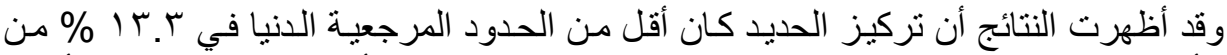

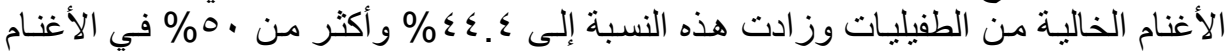

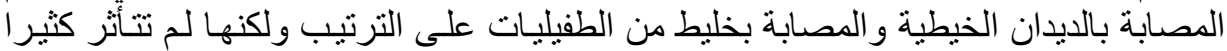

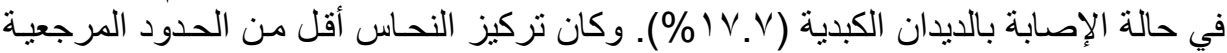

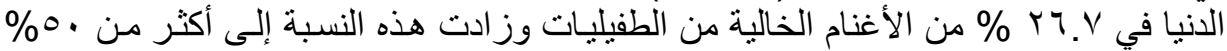

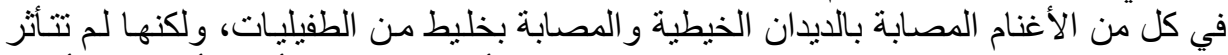

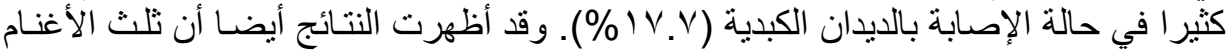

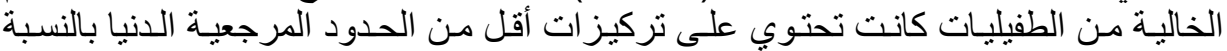

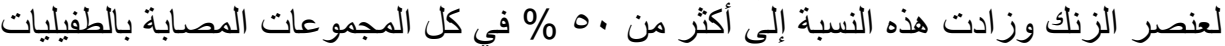

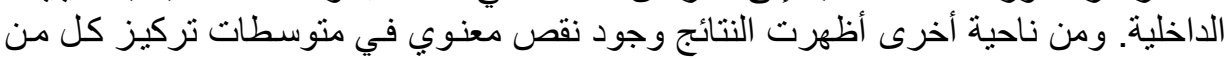

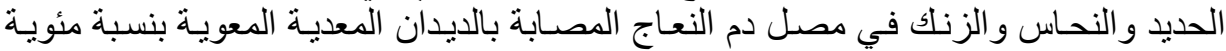

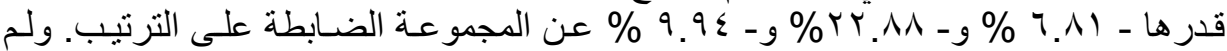




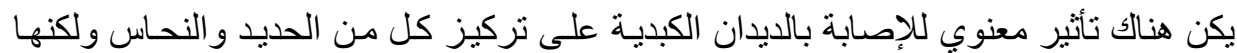

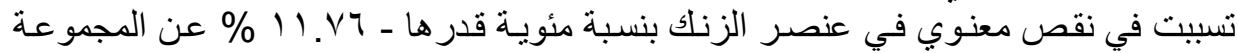

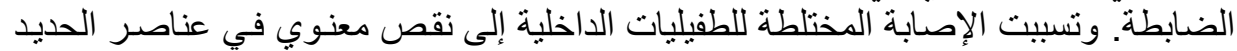

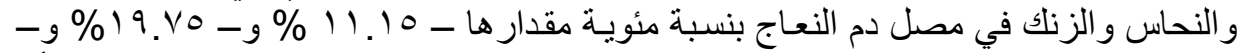

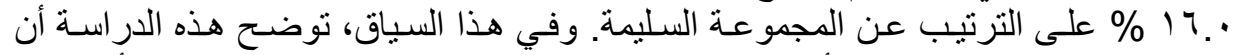

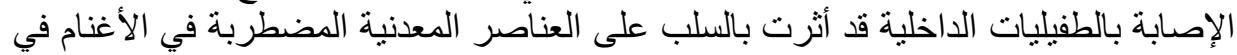

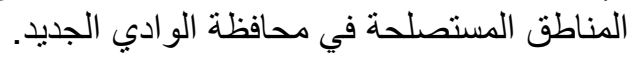

\section{SUMMARY}

Sheep reared in the recently reclaimed areas in the New-Valley governorate are suffering from mineral disorders due to disturbance in mineral concentrations in soil, water and pasture. The present work aimed to evaluate of the effect of internal parasitism as an interacting factor on the concentrations of blood serum iron, copper and zinc of sheep rearing in Darb Al-Arbaiyn area at the New Valley governorate. For this purpose, concentrations of blood serum iron, copper and zinc were estimated in 96 ewes classified according to parasitological investigations into 30 parasite free ewes (controls), 27 infected with gastrointestinal nematodes (GIT), 17 with fascioiasis and 22 with mixed infection. The results showed that $13.3 \%$ of normal sheep had lower iron values than the reference marginal values. This ratio increased up to $44.4 \%$ and more than $50 \%$ in GIT nematodes and mixed infection respectively, but it was not largely differed during fascioliasis (17.7\%). Concerning copper, it was $26.7 \%$ lower in clinically normal sheep than the reference marginal values. This value increased up to more than $50 \%$ in GIT nematodes and mixed infection, but it was not largely differed in sheep fascioliasis (17.7\%). The results showed also that third of normal sheep had lower zinc values than the reference marginal values. This value increased up to more than $50 \%$ in the all parasite infected sheep. On the other hand, the mean iron, copper and zinc concentrations were significantly decreased in blood serum of sheep infected by GIT nematodes with a percentage change of $-6.81 \%(\mathrm{P}=0.003),-22.88 \%$ $(\mathrm{P}=0.003)$ and $-9.94 \%(\mathrm{P}=0.040)$ than control animals respectively. Fascioliasis in sheep had insignificant effect on blood serum iron and copper but serum zinc concentration was significantly decreased in affected $(-11.76 \%, \mathrm{P}=0.023)$ than control sheep. There was a significant reduction in the mean values of iron, copper and zinc concentrations in sheep infested with mixed parasites with a percentage of $-11.15 \%$ $(\mathrm{P}=0.0001),-19.75 \% \quad(\mathrm{P}=0.017)$ and $-16.0 \% \quad(\mathrm{P}=0.007)$ than healthy 
animals respectively. In this concern, the infection with internal parasites could significantly exacerbate the existing trace elements deficiency in sheep at the recently reclaimed areas.

Key words: Copper, iron, zinc, sheep, gastrointestinal parasites, western Egyptian desert.

\section{INTRODUCTION}

Internal parasitism constitutes one of the greatest problems in grazing livestock worldwide (Kagira \& Kanyan, 2001; Keiser \& Utzinger, 2005 and Waller, 2006). It is considered as an important cause of health deterioration, chronic illthrift, poor growth rates, decreased productivity, reproductive failure, sudden death and serious economic loss (Over, et al., 1992; Urquhart, et al., 1996; Radostits, et al., 2000 and Schweizer, et al., 2005).

The status of trace elements in animal body is the mirror image of the health, growth and reproductive ability (Suttle and Jones 2000). Grazing livestock in tropical countries often do not receive mineral supplementation and depend almost exclusively on forages for their mineral nutrition. Only rarely, however, can tropical forages completely satisfy all mineral requirements (McDowell, 1997 \& 2003).

New-Valley governorate is an arid tropical area in the western Egyptian desert. It is considered one of the most promising areas for agricultural expansion in Egypt. Large areas are expected to be reclaimed and cultivated after transferring the Nile water to the Western Desert through Toshka canal.

There are several reports revealed a disturbance in mineral concentrations in the New-Valley soil, water and pasture (Saleh, 1996 \& 2000 and Khalil, et al., 2004). Recent studies had shown imbalance in concentrations of minerals in blood serum of sheep grazing in these areas (Yousef, 2006).

No reports had evaluated the effect of internal parasitism as an interacting factor on concentrations of trace elements in respect of mineral disturbances of sheep grazing in these newly reclaimed areas at the Egyptian oasis. The aim of the present work was evaluation of internal parasitism effects (particularly gastrointestinal nematodes and fascioliasis) on the concentrations of blood serum iron, copper and zinc of sheep rearing in Darb Al-Arbaiyn area in the New Valley governorate. 


\section{The study area:}

This study was carried out in Darb Al-Arbaiyn area as a recently reclaimed locality in the western Egyptian desert. This area is $77.8 \mathrm{~m}$ altitude and lies between $22^{\circ} 30^{\prime}$ and $25^{\circ} 40^{\prime} \mathrm{N}$ latitudes and between $29^{\circ} 42^{\prime}$ and $31^{\circ} 20^{\prime}$ E longitudes. Rainfall is almost negligible and the climate is arid, essentially that of the desert.

\section{Animals and diagnostic criteria:}

At Darb Al-Arbaiyn area sheep are grazing on seasonal crop residues or freely on perennial vegetation. Barseem (Medicago sativa) is usually offered for sheep when they indoors at afternoon. Sheep in this area are of Rahmani, Ossimi, Saidi and Barki breeds. The cross or mixed type of these breeds constitutes the major population of sheep in this area.

In this study a total of 96 non pregnant non lactating ewes (2-4 years) of mixed sheep were selected. The selection was based on faecal analysis for detection of gastrointestinal (GIT) nematode and liver fluke eggs by floatation sedimentation techniques after Coles (1986). Identification of GIT nematode eggs was carried out depending on the microscopical morphology of the eggs according to (Gerogi and Gerogi, 1990). A modified McMaster technique was used for faecal egg count (Soulsby, 1982). Individuals harboring >300 egg per gram (EPG) were considered clinically ill (Soulsby, 1982 and Urquhart, et al. 1996). Cases which were harboring other GIT parasites rather than GIT nematodes and liver flukes or those harboring nematodes eggs <300 EPG were excluded.

Accordingly, the investigated sheep were classified into four groups (Tab. 1). The first was internal parasite free (Group I, $n=30$ ) which was considered a healthy control group. The second was infected with single or mixed types of Osteatgia spp., Haemonchus spp. and or Trichostrongylus spp. (Group II, $\mathrm{n}=27$ ). The third group was infected with Faciola spp. (Group III, $\mathrm{n}=17$ ) and the fourth harbored mixed infection of GIT nematodes and Fasciola spp. (Group IV, n=22).

\section{Blood sampling:}

Blood was sampled from control and parasite infected sheep in vacuumed tubes (Terumo Europe N.V, Leuven, Belgium) without anticoagulant for collection of serum, which stored at $-20^{\circ} \mathrm{C}$ until biochemical analysis.

\section{Biochemical assay:}


Blood serum was used for determination of iron, copper and zinc concentrations by using acetylene type computerized atomic absorption technique (GBC, $932 \mathrm{AA}$ ) according to its manufacture guides.

\section{Statistical analysis:}

The data were subjected to standard one-way analysis of variance (ANOVA) followed by student " $t$ " test using SPSS program for windows version 10.0.1 (SPSS, 1999). Differences at $\mathrm{P} \leq 0.05$ were considered significant.

\section{RESULTS}

The mean concentrations of iron, copper and zinc in blood serum of control and parasite infected sheep are summarized in table 1 and figures $1 \& 2$. The mean iron, copper and zinc concentrations were significantly decreased in blood serum of sheep infected by GIT nematodes with a percentage change of $-6.81 \%(\mathrm{P}=0.003),-22.88 \%$ $(\mathrm{P}=0.003)$ and $-9.94 \%(\mathrm{P}=0.040)$ than normal respectively. Fascioliasis in sheep had insignificant effect on blood serum iron and copper. The change percent of reduction of these minerals in sheep infected with $F$. spp. than normal was - $3.41(\mathrm{P}=0.153)$ and $2.01(\mathrm{P}=0.802)$ respectively. On the other hand, the mean values of blood serum zinc concentration was significantly decreased $(-11.76 \%, \mathrm{P}=0.023)$ in Fasciola spp. infected sheep than normal. There was a reduction in the mean values of iron, copper and zinc concentrations in sheep infected with mixed parasites with a percentage of $-11.15 \%(\mathrm{P}=0.0001),-19.75 \%(\mathrm{P}=0.017)$ and $16.00 \%(\mathrm{P}=0.007)$ than controls respectively.

Percentages of blood serum concentrations of iron, copper and zinc below the reference marginal (subclinical) values in control and infected sheep are shown in table 2 and figure 3 . There were $13.3 \%$, $26.7 \%$ and $33.3 \%$ of control sheep had lower values of blood serum iron, copper and zinc respectively than the reference marginal values cited for sheep (McDowell, 2003). The respective percentages of reduction of these minerals than the reference values in GIT infected sheep were $44.4 \%, 51.9 \%$ and $51.9 \%$. There were $17.7 \%, 17.7 \%$ and $52.9 \%$ of sheep infected with Fasciola spp. had lower mean values of iron, copper and zinc respectively than the reference values cited for sheep. The respective values for mixed infected sheep were $54.6 \%, 54.6 \%$ and $63.6 \%$. 
Table 1: Blood serum trace element concentrations of control and infected sheep (mean $\pm \mathrm{SE}$, ranges, reference range, critical value and change $\%$ of the mean values of infected sheep than controls).

\begin{tabular}{|l|l|c|c|c|c|c|c|}
\hline & $\begin{array}{l}\text { Statistic } \\
\text { criteria }\end{array}$ & $\begin{array}{c}\text { Group I } \\
(\mathrm{N}=30)\end{array}$ & $\begin{array}{c}\text { Group II } \\
(\mathrm{N}=27)\end{array}$ & $\begin{array}{c}\text { Group III } \\
(\mathrm{N}=17)\end{array}$ & $\begin{array}{c}\text { Group IV } \\
(\mathrm{N}=22)\end{array}$ & $\begin{array}{c}\text { Reference } \\
\text { range* }\end{array}$ & $\begin{array}{c}\text { Critical } \\
\text { value** }\end{array}$ \\
\cline { 4 - 9 } $\begin{array}{l}\text { Iron } \\
(\mu \mathrm{mol} / \mathrm{L})\end{array}$ & Mean $\pm \mathrm{SE}$ & $32.3 \pm 0.43$ & $30.1 \pm 0.58$ & $31.2 \pm 0.63$ & $28.7 \pm 0.65$ & $29.7-39.7$ & $<12.54$ \\
& Range & $28.4-37.2$ & $25.2-35.2$ & $28.2-36.7$ & $24.1-34.9$ & & \\
& P-value & - & 0.003 & 0.153 & 0.0001 & & \\
& Change\% & - & -6.81 & -3.41 & -11.15 & & \\
\hline Copper & Mean \pm SE & $8.96 \pm 0.52$ & $6.91 \pm 0.39$ & $9.14 \pm 0.48$ & $7.19 \pm 0.50$ & $8-16$ & $<3.19$ \\
$(\mu \mathrm{mol} / \mathrm{L})$ & Range & $4.6-15.4$ & $4.6-12.1$ & $6.8-13.4$ & $3.9-12.3$ & & \\
& P-value & - & 0.003 & 0.802 & 0.017 & & \\
& Change\% & - & -22.88 & 2.01 & -19.75 & & \\
\hline Zinc & Mean \pm SE & $8.25 \pm 0.32$ & $7.43 \pm 0.21$ & $7.28 \pm 0.25$ & $6.93 \pm 0.35$ & $7.5-12.5$ & $<6.12$ \\
$(\mu \mathrm{mol} / \mathrm{L})$ & Range & $6.5-13.9$ & $6.2-10.1$ & $6.2-10$ & $4.3-10.1$ & & \\
& P-value & - & 0.040 & 0.023 & 0.007 & & \\
& Change\% & - & -9.94 & -11.76 & -16.00 & & \\
\hline
\end{tabular}

Group 1: Healthy control group; Group II: infected with GIT Nematodes; Group III: infected with Fasciola spp.; Group IV: infected with Mixed parasites. $*, * *$ Reference range and critical values are cited according to McDowell (2003).

Table 2: Percentages of blood serum concentrations of iron, copper and zinc below the reference ranges in control and infected sheep.

\begin{tabular}{|l|c|c|c|c|c|c|c|c|}
\hline & & \multicolumn{6}{|c|}{ Parasite infected sheep } \\
\cline { 4 - 9 } & Group I (n=30) & \multicolumn{6}{|c|}{ Group II (n=27) } & \multicolumn{2}{|c|}{ Group III (n=17) } & \multicolumn{2}{|c|}{ Group IV (n=22) } \\
\hline & Below & $\%$ & Below & $\%$ & Below & $\%$ & Below & $\%$ \\
\hline Iron & 4 & 13.33 & 12 & 44.44 & 3 & 17.65 & 12 & 54.55 \\
\hline Copper & 8 & 26.67 & 14 & 51.85 & 3 & 17.65 & 12 & 54.55 \\
\hline Zinc & 10 & 33.33 & 14 & 51.85 & 9 & 52.94 & 14 & 63.64 \\
\hline
\end{tabular}

Key of groups is illustrated in the footnote of table 1. 

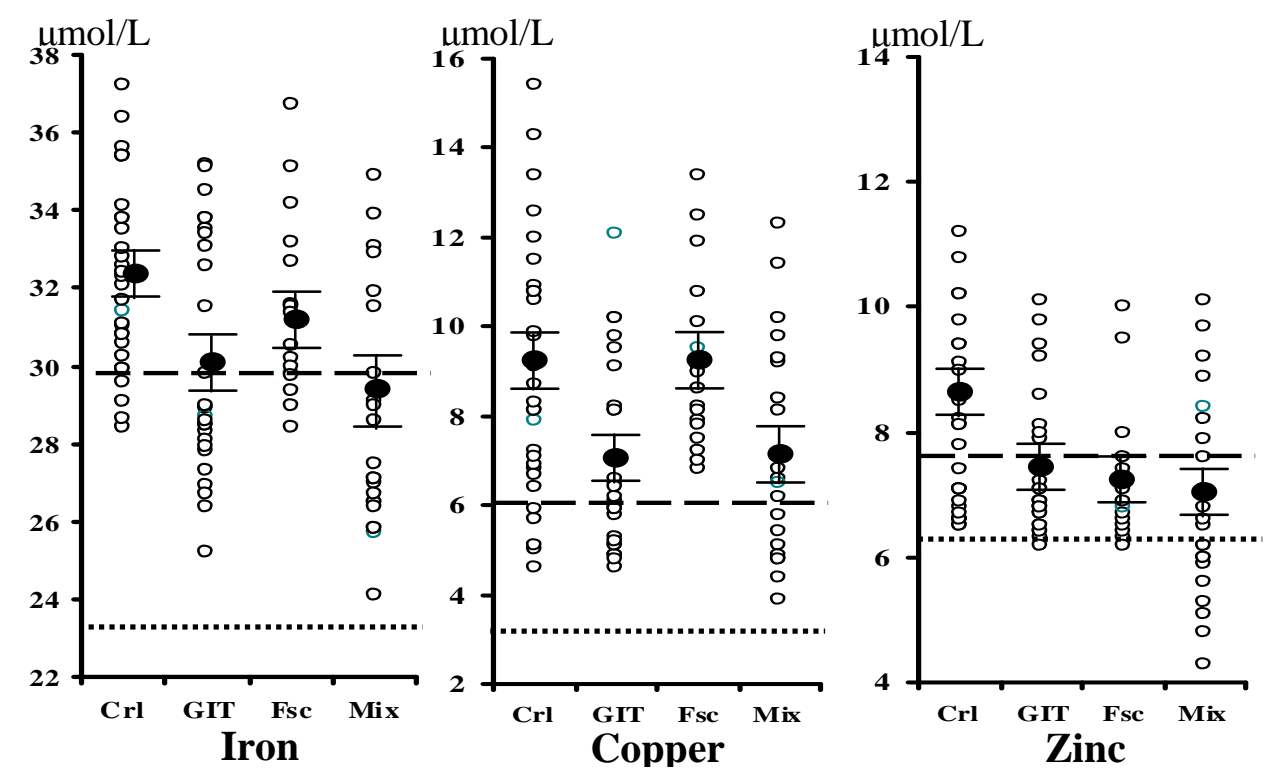

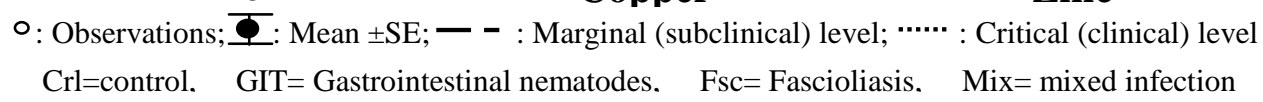

Fig. 1: Concentrations (observed ranges and mean $\pm \mathrm{SE}$ ) of trace elements in blood serum of control and internal parasites infected sheep. Marginal (subclinical) and critical (clinical) levels are cited according to and McDowell (2003).

Fe

$\mathrm{Cu}$

$\mathbf{Z n}$

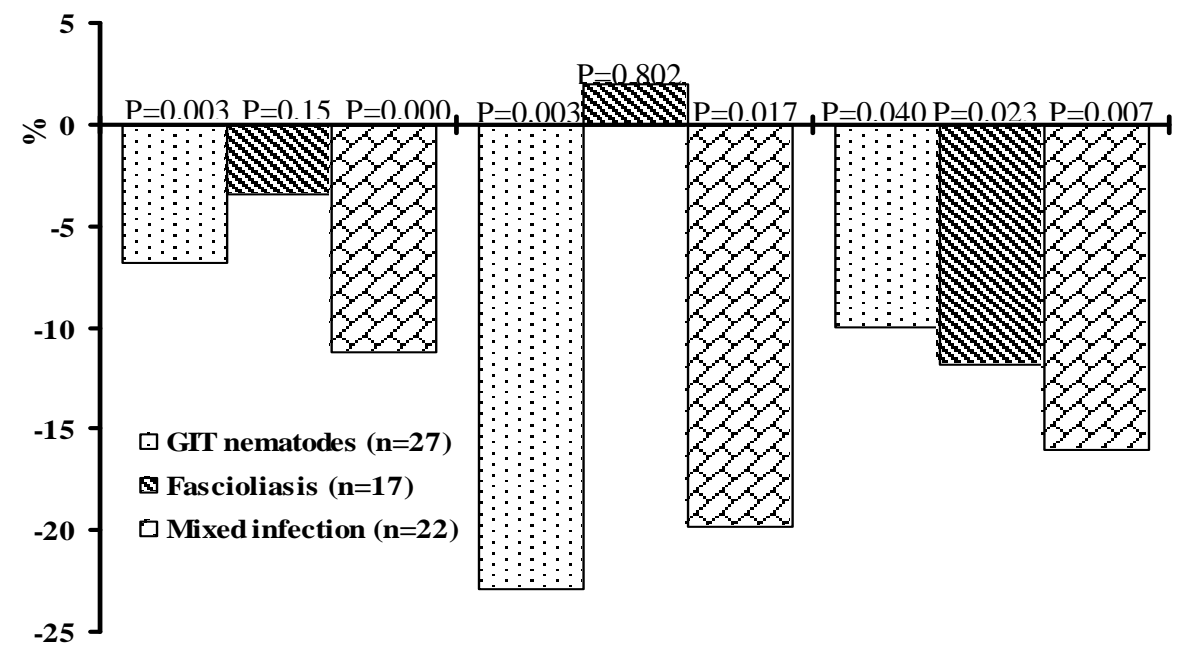

Fig. 2: Percentages of change of the mean values of trace element concentrations in blood serum of affected sheep than healthy control group (0\%) 


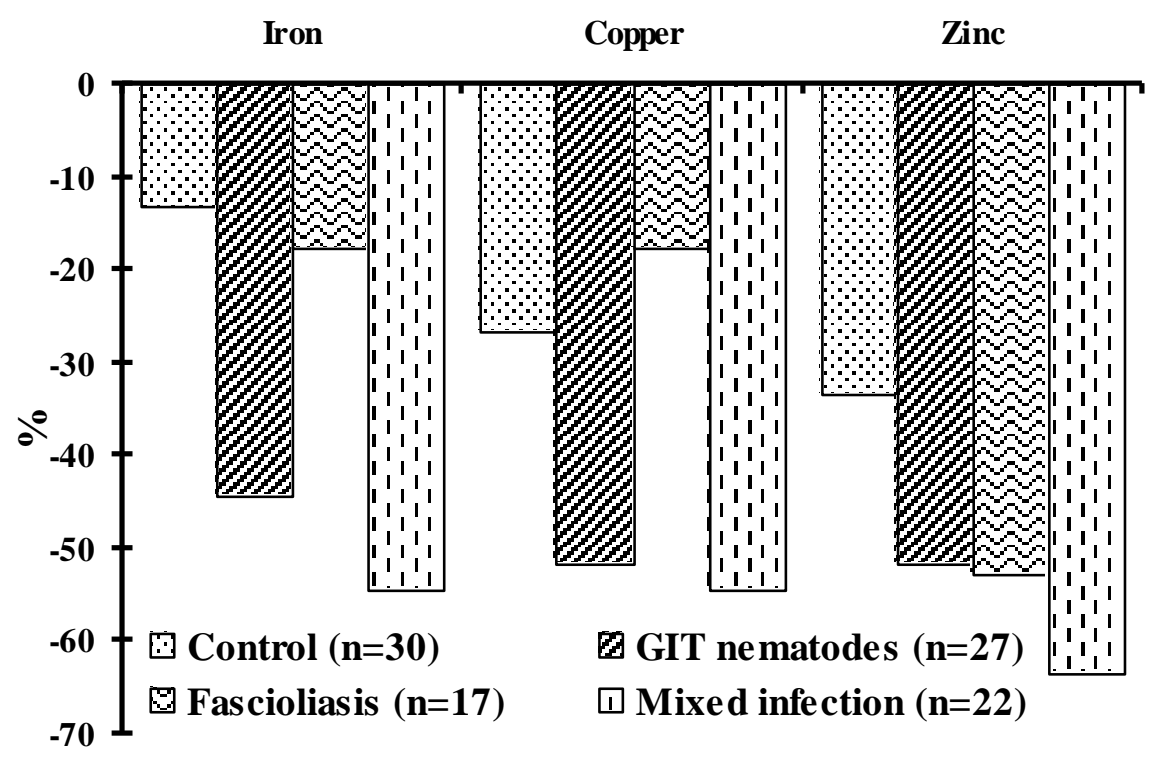

Fig. 3: Percentage of blood serum trace element values below the marginal reference (subclinical) values (McDowell, 2003) in control and infected sheep.

\section{DISCUSSION}

Micro-mineral deficiencies in sheep are inconsistently expressed and dependent on many factors (Sykes and Russel, 2000). Of these factors the soil and pasture type on which the animal reared (Suttle and Jones 2000). In the current work, the mean values of blood serum iron, copper and zinc in healthy sheep were within the reference ranges cited for sheep by McDowell (2003). However, there were 13.33\%, 26.67\% and $33.33 \%$ of the observed values of iron, copper and zinc concentrations in blood serum of sheep were lower than the reference marginal values $(29.7,8$ and $7.5 \mu \mathrm{mol} / \mathrm{L}$ respectively) cited for sheep by McDowell (2003). The sandy limestone nature of the soil, the low humus with subsequent disturbances in its mineral concentrations in addition to the soil alkalinity and the high $\mathrm{pH}$ which reaches 8-10 (Ismail, 1994; Khalil, et al., 2004) may play a role in the variations in mineral concentrations in the forages allowed to animals in this area, and in turn affect mineral concentrations in sheep (Yousef, 2006).

In the present study, iron was significantly decreased in blood serum of sheep infected with GIT nematodes and mixed infection than control animals $(-6.81 \%, \mathrm{P}=0.003$ and $-11.15 \%, \mathrm{P}=0.0001$ respectively) 
but it was not affected during fascioliasis $(-3.41 \%, \mathrm{P}=0.153)$. The results revealed that $44.44 \%, 17.65 \%$ and $54.55 \%$ of the mean blood serum iron values of infected sheep with GIT nematodes, F. spp. and mixed infection respectively were lower than the reference marginal values cited for blood serum iron of sheep (McDowell, 2003).

Iron deficiency seldom occurs in adult livestock (McDowell, 1997 \& 2003). During internal parasitic infection however, anemia due to iron deficiency can result from the direct loss of blood via bloodsucking parasites or through a rise in the rate of degradation of blood cells, and also through a depression of hematopoiesis from the action of toxic substances produced by the parasites (Urquhart, et al., 1996). Anaemia due to iron deficiency is a consistent clinical feature and has been recognized as a key symptom of the inflammatory gastrointestinal diseases (Gasche, et al., 2004). Under inflammatory conditions a diversion of iron traffic from the circulation to storage sites of the reticuloendothelial system occurs. This results in an iron-restricted erythropoiesis and the development of anemia, termed anemia of chronic disease (Weiss, 2005).

In the current investigation, copper was significantly decreased in blood serum of sheep infected with GIT nematodes and mixed infection than control animals $(-22.88 \%, \mathrm{P}=0.003$ and $-19.75 \%, \mathrm{P}=$ 0.017 ) but it was not affected during fascioliasis $(2.01 \%, \mathrm{P}=0.802)$. In this respect, $51.85 \%, 17.65 \%$ and $54.55 \%$ of the values of infected sheep with GIT nematodes, F. spp. and mixed infection respectively were lower than the reference marginal values cited for sheep (McDowell, 2003). This could be attributed on the bases that the absorption of copper is much lower in ruminants than in nonruminants (McDowell, 1997). The low absorption of this mineral in ruminants is due to modifications that occur in the rumen environment (Spears, 2003). Gastrointestinal parasites are thought to affect copper metabolism by interference with copper absorption from the gastrointestinal tract by increasing the $\mathrm{pH}$ of the gastric environment (Poppi, et al., 1990). Parasite can reduce the solubility of copper in the abomasum by up to 70 per cent, reduce the subsequent uptake of dissolved copper by the liver by up to 50 per cent and increase copper losses from the animal (Bank, et al., 1990). Suttle (1996) found also decreased serum copper in GIT infected sheep and the oral supplementations did not improve the case. Adogwa, et al., (2005) found loss of the effectiveness of cupper supplementation during GIT nematodes infection even by using parenteral administration and suggest that interference with absorption in the gastrointestinal tract is not the 
only mechanism by which the gastrointestinal parasites impede copper metabolism in the sheep.

In the present work, zinc was significantly decreased in blood serum of sheep with GIT nematodes, fascioliasis and mixed infection than control animals $(-9.94 \%, \mathrm{P}=0.040 ;-11.76 \%, \mathrm{P}=0.023$ and $-16.0 \%$, $\mathrm{P}=0.007$ respectively). Several reports revealed that the parasites destruct the absorptive epithelial cells in the gastrointestinal tract (Urquhart, et al., 1996; Aiello \& Mays, 1998). Recent studies showed that these cells synthesize numerous proinflammatory cell mediators including cytokines, chemokines, interleukins and growth factors (tumour necrosis factors) that modulate the activities of gut immune cells (Scott \& Koski, 2000; Simpson, 2000 and Failla, 2003). On the other hand Martínez-Moreno, et al. (2000) showed a free radical generation of peritoneal leukocytes and oxidative responses during Fasciola hepatica infection in small ruminants. Studies on liver affections have demonstrated a production of hepatic inflammatory infiltrates (Aboutwerat, et al., 2003; Basu 2003; Waldvogel, et al., 2004; Elizabeth and Molina 2005 and Molina and Skerratt, 2005). The observations of Brown (1998) suggest that zinc plays an important role in maintaining the proper balance between cell-mediated and humoral immunity by regulating patterns of proinflammatory cell mediators. Under these effects, $\mathrm{Zn}$ behaves as a negative acute phase reactant. In this aspect, hepatic synthesis of metallothionein (MT), an intracellular metal-binding protein is activated with a subsequent increase in hepatic zinc concentrations and decrease in plasma zinc values (Cousins, 1996; Cousins \& McMahon, 2000; Scott \& Koski, 2000; Wapnir, 2000 and Failla, 2003). Furthermore, Wapnir (2000) reported that the disrupted bowel generally entails poor absorption of zinc due to rapid transit in the gut, deterioration of the absorptive mucosa and loss of specific transporters. On the other hand, Hypoalbuminaemia was reported as a characteristic feature of internal parasites in ruminants (Hucker and Yong, 1986 and Thamsborg and Hauge, 2001). As zinc is transported in plasma bound to albumin (Cousins, 1996), the reduction of its circulating concentration during internal parasitic infection was expected.

According to the marginal reference (subclinical) values of blood serum iron cited for sheep (McDowell, 2003), 13.3\% of normal sheep had lower values than the marginal reference values $(29.7 \mu \mathrm{mol} / \mathrm{L})$. This ratio increased up to $44.4 \%$ and more than $50 \%$ in GIT nematodes and mixed infection respectively. For copper, $26.7 \%$ of normal sheep had 
lower values than the marginal reference values $(8.0 \mu \mathrm{mol} / \mathrm{L})$. This value increased up to more than $50 \%$ in GIT nematodes and mixed infection. Also, 33.3\% of normal sheep had lower zinc values than the marginal reference values $(7.5 \mu \mathrm{mol} / \mathrm{L})$. This value increased up to more than $50 \%$ in parasite infected sheep. Our results in this concern agree with the findings of Hucker and Yong (1986), Suttle (1996) and Adogwa, et al., (2005) who reported that internal parasitism worsen the already deficient minerals in sheep.

In conclusion, the infection with gastrointestinal parasites could significantly exacerbate the existing trace elements deficiency in sheep rearing in the recently reclaimed areas in the Egyptian oasis.

\section{REFERENCES}

Aboutwerat, A.; Pemberton, P.W.; Smith, A.; Burrows, P.C.; McMahon, R.F.T. and Jain, S.K. and Warnes, T.W. (2003): Oxidant stress is a significant feature of primary biliary cirrhosis. Biochimica et Biophysica Acta 1637: 142-150.

Adogwa, A.; Mutani, A.; Ramnanan, A. and Ezeokoli, C. (2005): The effect of gastrointestinal parasitism on blood copper and hemoglobin levels in sheep. Can. Vet. J. 46: 1017-1021.

Aiello, S.E. and Mays, A. (1998): The Merk Veterinary Manual. $8^{\text {th }}$ ed., Merk \& Co. Inc., White House Station, NJ, USA.

Bank, K.S; Familton, A.S. and Sykes, A.R. (1990): Effect of ostertagiasis on copper status in sheep: A study involving use of copper oxide wire particles. Res Vet Sci. 49: 306-314.

Basu, S. (2003): Carbon tetrachloride-induced lipid peroxidation: eicosanoid formation and their regulation by antioxidant nutrients. Toxicology 189: 113-127.

Brown, K.H. (1998): Effect of infections on plasma zinc concentration and implications for zinc status assessment in low-income countries. Am. J. Clin. Nutr. 68 (suppl): 425S-429S.

Coles, E.H. (1986): Veterinary clinical pathology. 4th ed., Saunders co. Philadelphia.

Cousins, R.J. (1996): Zinc. In: Ziegler, E.E. and Filer, L.J. eds. Present knowledge in nutrition. Washington, DC: ILSI Press pp. 293306.

Cousins, R.J. and McMahon, R.J. (2000): Integrative Aspects of Zinc Transporters. J. Nutr. 130: 1384S-1387S. 
Elizabeth, C. and Molina, E.C. (2005): Serum interferon-gamma and interleukins- 6 and -8 during infection with Fasciola gigantica in cattle and buffaloes. J. Vet. Sci. 6: 135-139.

Failla, M.L. (2003): Trace Elements and Host Defense: Recent Advances and Continuing Challenges. J. Nutr. 133:1443S$1447 \mathrm{~S}$.

Gasche, C.; Lomer, M.C.E.; Cavill, I. and Weiss, G. (2004): Iron, anaemia, and inflammatory bowel diseases. Gut 53: 11901197.

Gerogi, J.R. and Gerogi, M.F. (1990): Prarsitology for veterinarians $5^{\text {th }}$ ed. W. B. Saunders Company. New York.

Hucker, D.A. and Yong, W.K. (1986): Effects of concurrent copper deficiency and gastro-intestinal nematodiasis on circulating copper and protein levels, liver copper and bodyweight in sheep. Vet. Parasitol. 19: 67-76.

Ismail, K.M. (1994): Effect of fertilization, salinity of irrigation water and leaf/bunch ratio on the productivity of date palm in Elkharga, New-Valley. Ph. D. Thesis. Faculty of Agric. Assiut Univ.

Kagira, J. and Kanyan, P.W.N. (2001): The role of parasitic diseases as causes of mortality in small ruminants in a high-potential farming area in central Kenya. J. S. Afr. Vet. Ass. 72: 147-149.

Keiser, J. and Utzinger, J. (2005): Emerging Foodborne Trematodiasis. Emerging Infectious Diseases. 11: 1507-1514.

Khalil, M.N; Mohammad, I.R; Metwally, M.A. and Abdel-Khalik, M.A. (2004): Distribution of some nutrients in certain soils of the New Valley governorate. Zagazig J. Agric. Res. 31: 22872314.

Martínez-Moreno, A.; JimeÂnez-Luque, V.; Martínez-Moreno, S.C.J.; Acosta, I. and Hernández, S. (2000): Oxidative responses during bacterial phagocytosis of polymorphonuclear leucocytes in primarily and secondarily Fasciola hepatica infected goats. International J. Parasit. 30: 1013-1017.

McDowell, L.R. (1997): Minerals for Grazing Ruminants in Tropical Regions. $3^{\text {rd }}$ Edition, Dept. of Animal Science Bulletin, Center for Tropical Agriculture, Univ. of Fla, Gainesville.

McDowell, L.R. (2003): Minerals in Animal and Human Nutrition, $2^{\text {nd }}$ ed. Elsevier Science, Amsterdam. 
Molina, E. and Skerratt, L.F. (2005): Cellular and humoral responses in liver of cattle and buffaloes infected with a single dose of Fasciola gigantica. Vet. Parasitology 131: 157-163.

Over, H.J.; Jansen, J. and Van Olm, P.W. (1992): Distribution and Impact of Helminth Diseases of Livestock in Developing Countries, FAO Animal Production and Health Paper 96, Rome, 1992.

Poppi, D.P.; Sykes, A.R. and Dynes, R.A. (1990): The effect of endoparasitism on host nutrition - the implications for nutrient manipulation. Proc. NZ Soc. Anim. Prod. 50: 237-243.

Radostits, O.M.; Gay, C.C.; Blood, D.C. and Hinchcliff, K.W. (2000): Veterinary Medicine, $9^{\text {th }}$ Ed. (Baillier Tindall, London, Philadelphia, New York).

Saleh, M.A. (1996): Environmental factors affecting health of Friesian and native cattle in New-Valley Governorate. Ph. D. Thesis, Fac. Vet. Med. Assiut Univ.

Saleh, M.A. (2000): Prevalence, causes and types of iodine deficiency disorders (IDD) in Egyptian oasis sheep. Egypt. J. of Agric. Res. 78: 167-174.

Schweizer, G.; Braun, U.; Deplazes, P. and Torgerson, P.R. (2005): Estimating the financial losses due to bovine fasciolosis in Switzerland. Vet Rec. 157: 188-193.

Scott, M.E. and Koski, K.G. (2000): Zinc impairs immune responses against parasitic nematode infections at intestinal and systemic sites. J. Nutr. 130: 1412S-1420S.

Simpson, H.V. (2000): Pathophysiology of abomasal parasitism: Is the host or parasite responsible. Vet. J. 160: 177-191.

Soulsby, E.J.L. (1982): Helminth, arthropods and protozoa of domesticated animals. $7^{\text {th }}$ ed. The English language book Society Balliere, Tindall and Cassel. London.

Spears, J.W. (2003): Trace Mineral Bioavailability in Ruminants. J. Nutr. 133: 1506S-1509S.

SPSS, (1999): ANOVA in Sample Power Statistics, SPSS, 10.0.1 Syntax Reference Guide for SPSS Base. SPSS Inc., 233 South Wacker Drive, Chicago, IL.

Suttle, N.F. (1996): Non-dietary influences on the mineral requirements of sheep. In: Masters, D.G. and White, C.L. (eds) Detection and Treatment of Mineral Nutrition Problems in Grazing Sheep. Monograph No. 37, ACIAR, Canberra, pp. 31-44. 
Suttle, N.F. and Jones, D.J. (2000): Micronutrient imbalance, In: Diseases of Sheep, $3^{\text {rd }}$ ed., Martin, W.B. and Aitken, I.D. ed., Blackwell Science, Oxford, Tokyo, Berlin. pp. 332-344.

Sykes, A.R. and Russel, A.J.F. (2000): Deficiency of mineral macroelements. In: Diseases of Sheep, $3^{\text {rd }}$ ed., Martin, W.B. and Aitken, I.D. ed., Blackwell Science, Oxford, Tokyo, Berlin. pp 318-331.

Thamsborg, S.M. and Hauge, E.M. (2001): Osteopenia and reduced serum alkaline phosphatase activity in grazing lambs naturally infected with gastrointestinal nematodes. J. Comp. Pathol. 125: 192-203.

Urquhart, G.M.; Armour, J.; Duncan, J.L.; Dunn, A.M. and Jennings, F. $W$. (1996): Veterinary parasitology, $2^{\text {nd }}$ ed., Blackwell Science.

Waldvogel, A.S.; Lepage, M.F.; Zakher, A.; Reichel, M.P.; Eicher, R. and Heussler, V.T. (2004): Expression of interleukin 4, interleukin 4 splice variants and interferon gamma mRNA in calves experimentally infected with Fasciola hepatica. Vet. Immunol Immunopathol, 97: 53-63.

Waller, P.J. (2006): Sustainable nematode parasite control strategies for ruminant livestock by grazing management and biological control. Animal Feed Science and Technology, 126: 277-289.

Wapnir, R.A. (2000): Zinc deficiency, malnutrition and the gastrointestinal tract. J. Nutr. 130: 1388S-1392S.

Weiss, G. (2005): Modification of iron regulation by the inflammatory response. Best Practice Research. Clinical Haematoogy. 18: 183-201.

Yousef, E.M. (2006): Some minerals profile in sheep serum in NewValley Governorate, M. Vet. Sci. Fac. Vet. Med. Assiut Univ. 